\title{
Preparation and neutralization efficacy of IgY antibodies raised against Deinagkistrodon acutus venom
}

Jinhua Liu', Qiyi He', Wenwen Wang ${ }^{1}$, Bin Zhou², Bo Li', Yingfeng Zhang ${ }^{1}$, Cong Luo ${ }^{1}$, Diancheng Chen ${ }^{1}$, Jia Tang ${ }^{1}$ and Xiaodong $\mathrm{Yu}^{{ }^{*}}$

\begin{abstract}
Background: The five-paced pit viper (Deinagkistrodon acutus), endemic to China and northern Vietnam, is responsible for most snakebites in the Chinese territory. Antivenom produced from horses is the main treatment for snakebites, but it may cause numerous clinical side effects and have other disadvantages involved in their production such as the welfare of animals. The present study was conducted aiming to develop an alternative antibody (IgY) from the egg yolk of leghorn chickens immunized with snake venom.

Methods: IgY from the egg yolk of white leghorn chickens previously immunized intramuscularly with D. acutus venom was extracted by water, precipitated by ammonium sulfate and purified by affinity chromatographic system. IgY was identified by SDS-PAGE, ELISA and Western blot. Finally, IgY neutralization assays to test its efficacy against hemorrhagic, edema-forming and myotoxic activities of $D$. acutus venom were conducted on mice.

Results: For the first time, IgY antibodies against $D$. acutus venom were raised successfully in egg yolk of chickens injected with D. acutus venom multiple times. By three steps, including caprylic acid extraction, ammonium sulfate precipitation and affinity chromatography, IgY antibodies were isolated and purified from egg yolk, which exhibited a single protein band on SDS-PAGE and two bands (about $65 \mathrm{kDa}$ and $35 \mathrm{kDa}$, respectively) under reducing conditions, and presented a high titer $(1: 40,000)$ tested by ELISA. Immunoblot analysis confirmed that these IgY were polyclonal antibodies since they bound to components of $D$. acutus venom. Furthermore, immunodiffusion assay showed that anti-D. acutus venom IgY cross-reacted with the venoms of Trimeresurus albolabris and D. saxatilis Emelianov, but did not react to the venoms of Bungarus multicinctus and Naja atra. In the neutralizing lethal assay, the median effective dose of anti-D. acutus venom IgY was $14.14 \mathrm{mg} / \mathrm{kg}$ of mouse body weight under the challenge dose (3 $L D_{50}$ of $D$. acutus venom). In neutralizing the hemorrhagic, edema-forming and myotoxic activities of $D$. acutus venom, IgY showed the characteristic dose-dependent neutralization effects against all these toxic activities of $D$. acutus venom.

Conclusion: Anti-D. acutus venom IgY antibodies with high purity and titer were for the first time raised successfully in egg yolk of chickens immunized with D. acutus venom. They were effective in neutralizing the lethal effects, and the hemorrhagic, edema-forming and myotoxic acitivities of D. acutus venom. IgY could be an effective source to develop a treatment against snake bites in humans or animals in the future.
\end{abstract}

Keywords: IgY antibody, Egg yolk, Snake venom, Snakebite, Deinagkistrodon acutus, Venom neutralization

\footnotetext{
* Correspondence: yxd@cqnu.edu.cn

${ }^{1}$ Animal Toxin Group, Chongqing Key Laboratory of Animal Biology,

Chongqing Engineering Research Center of Bioactive Substances,

Engineering Research Center of Active Substances and Biotechnology,

Ministry of Education, College of Life Science, Chongqing 401331, China

Full list of author information is available at the end of the article
}

(c) The Author(s). 2017 Open Access This article is distributed under the terms of the Creative Commons Attribution 4.0 International License (http://creativecommons.org/licenses/by/4.0/), which permits unrestricted use, distribution, and reproduction in any medium, provided you give appropriate credit to the original author(s) and the source, provide a link to the Creative Commons license, and indicate if changes were made. The Creative Commons Public Domain Dedication waiver (http://creativecommons.org/publicdomain/zero/1.0/) applies to the data made available in this article, unless otherwise stated. 


\section{Background}

Snake envenomation is an important public health issue in the world. There are more than 420 species of venomous snakes, which are widely distributed throughout the globe (including oceans), except for a few islands, frozen environments and high-altitude regions. These animals provokes 5.4 million bites, about 2.5 million of envenomation cases and over 0.125 million of deaths annually. As is well known, the highest burden of snakebites is found in South Asia, Southeast Asia and sub-Saharan Africa [1-4]. In addition, the burden of snakebites is heavy in China, where there are over 50 species of venomous snakes. One species, the fivepaced pit viper (Deinagkistrodon acutus), is responsible for most snakebites in the country. It is a large sized and highly venomous snake, found from the southern provinces of China (including Taiwan) to northern Vietnam [5, 6].

The intravenous administration of antivenom is the mainstay treatment for envenomated victims. The conventional antivenom is generally produced from the blood of the large animals, frequently horses or sheep, immunized with the venom of a single snake or mixed venoms obtained from several animals to eliminate the intraspecific diversification [7]. Nevertheless, the serum used to treat snakebite victims may cause various side effects, such as anaphylactic shock, pyrogen reaction and serum sickness, which are mainly caused by the nonspecific proteins found in commercially available antivenoms [8-11]. Moreover, frequent immunization and bleeding during antivenom production may cause great distress to the employed animals. In addition, the production of sufficient pure serum antibodies against snake venom may require more investment and time, which may be conflicting with interests of serum manufacturers, especially in developing countries. Thus, it is necessary to find an alternative way of antibody creation, which would be safer, cheaper, short-cycle and noninvasive.

In recent years, eggs of chicken immunized with antigens have been recognized as a good source of IgY antibodies [12-14]. So far, many research results about snake antivenom IgY have demonstrated that IgY in eggs of chicken is an excellent alternative to the conventional antivenom produced in large mammals $[15,16]$. The main advantages of IgY include:

- collecting eggs instead of bleeding animal meets the animal welfare requirement;

- the cost of keeping hens is lower than that of raising horses or sheep;

- IgY antibodies do not cross-react with Fc receptors, thereby reducing the cause of false positive results in immunological assays;
- IgY, like mammalian IgG, is a reasonable stable protein over time;

- the yield of IgY is large and its production may be readily scalable [17-20].

In this study, hens were hyperimmunized with low doses of $D$. acutus venom to produce specific antibodies. IgY was extracted from egg yolk and further purified by affinity chromatography. Subsequently, we assessed and examined the purity, the binding specificity, the titer and the neutralization efficiency of IgY. All the results will provide a basis for developing IgY into a clinical agent in the future.

\section{Methods}

\section{Reagent and supplies}

Freund's complete adjuvant (FCA), Freund's incomplete adjuvant (FIA), rabbit anti-IgY peroxidase conjugate, Immobilon ${ }^{\oplus} \mathrm{P}$ (polyvinylidene difluoride, PVDF), a transfer membrane with pore size of $0.45 \mu \mathrm{m}, 3^{1}, 3^{1}, 5^{1}, 5^{1}$-tetramethylbenzidine (TMB), nonfat dry milk and horseradish peroxidase-conjugated rabbit anti-chicken IgY were purchased from Sigma (USA). Polystyrene ELISA plates were purchased from Corning (USA). Amicon ultra-15 centrifugal filter devices were obtained from Millipore (USA). NHS activated Sepharose 4 FF were purchased from GE Healthcare (UK). Protein molecular weight markers were purchased from Takara (Japan). All the other reagents were of analytical grade.

\section{Venom}

Venom was obtained from $D$. acutus captured at Wulingshan in Chongqing, China. Venom was lyophilized in a ModulyoD-230 freeze dryer (Thermo Scientific) and stored at $-20{ }^{\circ} \mathrm{C}$ until use.

\section{Animal}

Seventeen-week-old white leghorn hens weighing $1.5 \mathrm{~kg}$ each, purchased from a local poultry farm, in good health and laying conditions (laying 5 to 6 eggs per week) were used for the production of IgY against snake venom. They were kept in individual cages with standard food and water. Kunming mice (18-20 g) were purchased from experimental animal center of Third Military Medical University. Mice were kept in plastic boxes at five per cage, in a room maintained at $20-23{ }^{\circ} \mathrm{C}$ on a 12/12-h light/dark cycle with food and water ad libitum.

\section{Immunization schedule}

Based on the $\mathrm{LD}_{50}$ of $D$. acutus venom for mice (about $2.93 \mathrm{mg} / \mathrm{kg}$, intraperitoneally), the $\mathrm{LD}_{50}$ of $D$. acutus venom for laying hens was calculated to be $0.72 \mathrm{mg} / \mathrm{kg}$. Each hen was immunized intramuscularly at multiple 
sites in the breast region with $0.5 \mathrm{~mL}$ saline (containing $0.29 \mathrm{mg}$ snake venom) emulsified with an equal volume of FCA. On the $14^{\text {th }}, 35^{\text {th }}$ and $56^{\text {th }}$ day after the first immunization, booster doses were administered with $0.5 \mathrm{~mL}$ saline (containing $0.58 \mathrm{mg}, 1.17 \mathrm{mg}$ and $1.17 \mathrm{mg}$ snake venom, respectively) emulsified with an equal volume of FIA. Serum was collected weekly from the first immunization, but after the $10^{\text {th }}$ week serum was collected every 2 weeks. Eggs began to be collected daily before the first immunization and the collecting eggs sustained for 24 weeks after the first immunization. The control group of hens was immunized intramuscularly with $0.5 \mathrm{~mL}$ saline. Serum was stored at $-20{ }^{\circ} \mathrm{C}$ and eggs at $4{ }^{\circ} \mathrm{C}$ until use.

\section{Extracting antibody from egg yolk}

Extraction of IgY from preimmunized and hyperimmunized eggs was performed according to our previous method with minor modifications [21]. Briefly, the egg shell was cracked and the yolk was separated from the egg white. The yolk contents was diluted 7.5-fold with deionized water and homogenized by stirring vigorously for $30 \mathrm{~min}$ on magnetic stirrer. The resulting homogenate was further diluted 2-fold with $0.04 \mathrm{M}$ acetate buffer $(\mathrm{pH} 5.0$, containing $0.06 \mathrm{M} \mathrm{NaCl}$ ) and again homogenized for 30 min while adding caprylic acid up to final concentration of $1 \%$. The preparation was placed at room temperature for $4 \mathrm{~h}$. The clear supernatant, the water-soluble fraction (WSF), was siphoned out and centrifuged at $10,000 \mathrm{rpm}$ for $10 \mathrm{~min}$ at $4{ }^{\circ} \mathrm{C}$. The $\mathrm{IgY}$ in water-soluble fraction was precipitated out with $45 \%$ ammonium sulfate. The salt pellets were dissolved in phosphate buffered saline (PBS, pH 7.4) and dialyzed against PBS. Finally, the partially purified antibody preparation (crude extract) was subjected to affinity chromatography.

\section{Affinity purification}

The venom affinity column in chromatographic system (ÄKTA purifier 100, GE) was prepared as follows: in brief, NHS activated Sepharose 4FF were coupled with whole venom of $D$. acutus dissolved in coupling buffer $(0.2 \mathrm{M} \mathrm{NaHCO}, \mathrm{pH}$ 8.3, containing $0.5 \mathrm{M} \mathrm{NaCl}$ ). Unreacted groups on the Sepharose were blocked with $0.5 \mathrm{M}$ ethanolamine buffer ( $\mathrm{pH} 8.3$, containing $0.5 \mathrm{M}$ $\mathrm{NaCl}$ ). Finally, the Sepharose was washed with Tris- $\mathrm{HCl}$ buffer $(0.05 \mathrm{M}, \mathrm{pH} 9.0)$ and then acetate buffer $(0.05 \mathrm{M}$, $\mathrm{pH}$ 5.0). The Sepharose was packed into a column that was equilibrated with PBS buffer $(0.01 \mathrm{M}, \mathrm{pH}$ 7.4). The crude extract (ant-D. acutus IgY, $20 \mathrm{mg} / \mathrm{mL}$ ) was loaded into the affinity column, and the column was washed with PBS buffer (0.01 M, pH 7.4) to remove the unabsorbed proteins. The bound antibodies were eluted with glycine- $\mathrm{HCl}$ buffer $(0.1 \mathrm{M}, \mathrm{pH} 2.3)$, and pooled, concentrated and desalted through Amicon Ultra-15 centrifugal filter devices, then stored at $4{ }^{\circ} \mathrm{C}$.

\section{Protein concentration}

Protein concentration was measured as described by Lowry et al. [22].

\section{SDS-PAGE}

The purity and molecular weight of the IgY were analyzed on $12 \%$ sodium dodecyl sulfate-polyacrylamide gel electrophoresis (SDS-PAGE), according to the method of Laemmli [23].

\section{Western blot}

It was carried out according to the procedure of Towbin et al. [24] with minor modifications. D. acutus venom $(50 \mu \mathrm{g})$ were separated on $15 \%$ non-reducing SDSPAGE, and then electroblotted onto PVDF membrane that was treated with methanol before. The unreacted sites on membrane were blocked with a blocking solution (5\% nonfat milk in PBS buffer, $\mathrm{pH} 7.4$ and containing $0.05 \%$ Tween-20) at room temperature for $2 \mathrm{~h}$ on a horizontal shaker, then incubated with the affinitypurified anti- $D$. acutus IgY for $1 \mathrm{~h}$ at room temperature. Next, the blot was washed five times with rinse buffer and incubated with horseradish peroxidase-conjugated rabbit anti-chicken IgY (1: 5000). Finally, the blots were washed and specific blots of venom proteins bound to IgY were visualized using peroxidase chromogenic substrate solution TMB.

\section{Immunodiffusion assay}

The specificity of IgY against snake venom components was demonstrated with agar diffusion test (1\% agarose) described by Ouchterlony [25]. D. acutus venom was added into the center well in an agar plate, the different concentrations of anti- $D$. acutus IgY antibodies were loaded into the peripheral wells, and then the plate was incubated for $24 \mathrm{~h}$ at $37{ }^{\circ} \mathrm{C}$ to observe the antigenantibody reactive lines. In addition, the cross reactivity between anti- $D$. acutus IgY and four other snake venoms (Trimeresurus albolabris, A. saxatilis, Bungarus multicinctus and Naja atra from China) was also evaluated by this test.

\section{ELISA assay}

ELISA was used to assess the activities of anti-D. acutus IgY antibodies in serum and the yolk [21]. The microplates were coated with $1 \mu \mathrm{g}$ native $D$. acutus venom in $100 \mu \mathrm{L}$ coating buffer $(0.05 \mathrm{M}$ carbonate bicarbonate, $\mathrm{pH}$ 9.6) for $14 \mathrm{~h}$ at $4{ }^{\circ} \mathrm{C}$ and the wells were washed with rinse buffer (PBS-0.05\% Tween 20, $\mathrm{pH} 7.4$ ). Then, the unbound sites were blocked for $1.5 \mathrm{~h}$ at $37{ }^{\circ} \mathrm{C}$ with $200 \mu \mathrm{L}$ blocking buffer (rinse buffer plus 5\% nonfat dry 
milk). The coated wells were washed again, and then were added to the serum or the yolk diluted in dilution buffer (PBS plus 1\% nonfat dry milk) and incubated $1 \mathrm{~h}$ at $37{ }^{\circ} \mathrm{C}$. After the wells were washed three times, they were added to the rabbit anti-IgY-peroxidase dilution (1:5000) and incubated for $1 \mathrm{~h}$ at $37^{\circ} \mathrm{C}$. After the wells were washed once again, $200 \mu \mathrm{L}$ of TMB was added and incubated at room temperature for $20 \mathrm{~min}$. The reactions were terminated with $50 \mu \mathrm{L}$ of $2 \mathrm{M}$ sulfuric acid. Absorbance was recorded at $450 \mathrm{~nm}$ using ELISA plate reader. Results determination: a positive sample and a negative sample need to give a ratio of at least 2.1 (that is, OD of the positive divided by OD of the negative. $\mathrm{P} / \mathrm{N}>2.1$ ).

\section{Neutralization of venom lethality by $\lg \mathrm{Y}$}

The ability of $\operatorname{IgY}$ to neutralize lethality of $D$. acutus venom was assessed by an in vivo neutralization test. Various amounts of the purified antivenom $\operatorname{IgY}(50 \mu \mathrm{g}$, $100 \mu \mathrm{g}, 200 \mu \mathrm{g}, 400 \mu \mathrm{g}, 800 \mu \mathrm{g}$ and $1600 \mu \mathrm{g}$, respectively) were mixed with the challenge dose $\left(3 \mathrm{LD}_{50}\right.$ dose of $D$. acutus venom) and incubated for $30 \mathrm{~min}$ at $37^{\circ} \mathrm{C}$, centrifuged for $5 \mathrm{~min}$, then $20 \mu \mathrm{L}$ of the supernatant was injected intraperitoneally into groups of 10 mice. Control mice received the same amount of venom mixed with the normal yolk. The deaths were recorded over $72 \mathrm{~h}$. The $\mathrm{ED}_{50}$ was calculated according to the recommendation of WHO [26] and expressed as $\mathrm{mg} I g Y / \mathrm{kg}$ body weight.

\section{Neutralization of hemorrhagic activity by $\lg \mathrm{Y}$}

Hemorrhagic activity was quantitatively determined according to the method of Gutiérrez et al. [27]. Various amounts of venom $(0,5 \mu \mathrm{g}, 10 \mu \mathrm{g}, 15 \mu \mathrm{g}, 20 \mu \mathrm{g}$ and $25 \mu \mathrm{g})$ diluted in $0.1 \mathrm{~mL}$ physiological saline $(0.9 \% \mathrm{w} / \mathrm{v})$ were injected subcutaneously into the dorsal skin of groups of four mice. Two hours later, they were sacrificed and their dorsal skin was removed, and the diameter of the hemorrhagic spot was measured. Physiological saline was utilized as negative control. Diameters were calculated and the minimum hemorrhagic dose (MHD) was defined as the dose of venom that induced a lesion of $10 \mathrm{~mm}$ of diameter $2 \mathrm{~h}$ after injection. The challenge doses of venom (3 MHD) was incubated with various amounts of IgY antibodies $(0,500 \mu \mathrm{g}, 1000 \mu \mathrm{g}, 1500 \mu \mathrm{g}, 2500 \mu \mathrm{g}$, and $3500 \mu \mathrm{g}$ ) for $30 \mathrm{~min}$ at $37^{\circ} \mathrm{C}$, centrifuged for $5 \mathrm{~min}$. Then, $10 \mu \mathrm{L}$ of the supernatant was subcutaneously injected into the dorsal skin of groups of ten mice. Control group received normal yolk (the same amount of used for venom). Hemorrhage was expressed as a percentage, taking as $100 \%$ the diameter of the lesions induced by inoculating 10 MHD of venom alone. Results were plotted and the $\mathrm{ED}_{50}$ was defined as the ratio of IgY/venom that decreased the activity by $50 \%$.

\section{Neutralization of edema-forming activity by $\lg Y$}

Edema-forming activity was quantitatively determined according to the method of Van Dong et al. [28]. There are groups of 4 mice injected subcutaneously, in the right footpad, with $20 \mu \mathrm{L}$ of various amounts of venom $(0.1 \mu \mathrm{g}, 0.5 \mu \mathrm{g}, 1 \mu \mathrm{g}, 1.5 \mu \mathrm{g}$ and $2.0 \mu \mathrm{g})$ dissolved in physiological saline $(0.9 \% \mathrm{w} / \mathrm{v})$, and in the left footpad received $20 \mu \mathrm{L}$ of the physiological saline. The weight of each foot was determined $3 \mathrm{~h}$ after injection with an electrionic scale. The minimum edema-forming dose (MED) corresponds to the amount of venom that induces an increment of $30 \%$ in the weight of the foot envenomated for $3 \mathrm{~h}$ when compared with the physiological saline-injected foot. The challenge doses of venom (3 MED) was incubated with various amounts of the IgY antibodies $(25 \mu \mathrm{g}, 50 \mu \mathrm{g}, 100 \mu \mathrm{g}, 150 \mu \mathrm{g}$ and $200 \mu \mathrm{g}$ ) for $30 \mathrm{~min}$ at $37^{\circ} \mathrm{C}$, centrifuged for $5 \mathrm{~min}$, then $20 \mu \mathrm{L}$ of the supernatant was injected subcutaneously into groups of 10 mice in the right footpad.

\section{Neutralization of myotoxic activity by lgY}

Myotoxic activity was quantitatively determined according to the method of Rojas et al. [29]. Various amounts of venom $(0 \mu \mathrm{g}, 5 \mu \mathrm{g}, 10 \mu \mathrm{g}, 15 \mu \mathrm{g}, 20 \mu \mathrm{g}$ and $25 \mu \mathrm{g})$ dissolved in $50 \mu \mathrm{L}$ of physiological saline $(0.9 \% \mathrm{w} / \mathrm{v})$ were injected intramuscularly (i.m.) into groups of 4 mice in the right gastrocnemius muscle. Control animals received $50 \mu \mathrm{L}$ of the physiological saline. Three hours after injection, mice were bled from the orbital plexus, under $\mathrm{CO}_{2}$ anesthesia. Plasma creatine kinase (CK) activity was quantitated by the CK kit (Nanjing Jiancheng Corp. China). CK activity is expressed in units/L, $1 \mathrm{U}$ defined as the amount of enzyme that produces $1 \mu \mathrm{mol}$ of NADH under the conditions of the assay. The minimum myotoxic dose (MMD) corresponds to the amount of venom that induces an increment of plasma CK activity corresponding to four times the activity of mice injected with physiological saline alone. The challenge doses of venom (3 MMD) was incubated with various amounts of the IgY antibodies $(0,375 \mu \mathrm{g}, 750 \mu \mathrm{g}$, $1500 \mu \mathrm{g}$ and $3000 \mu \mathrm{g}$ ) for $45 \mathrm{~min}$ at $37^{\circ} \mathrm{C}$ and centrifuged for $5 \mathrm{~min}$. Then, $50 \mu \mathrm{L}$ of the supernatant was injected subcutaneously into groups of ten mice in in the right gastrocnemius muscle.

\section{Statistical analysis}

Statistical calculations were performed using GraphPad Prime 5.0. Results were presented as mean \pm SEM values. The ANOVA was used to test differences among groups. The differences between the mean values were determined by the Student's test and the differences were considered statistically significant at $p<0.05$. 


\section{Results}

\section{Antibody response}

Following primary immunization, the hens produced comparable antibody response that was detected in serum by day 8 . Although the pre-booster response was low in the serum, after the first booster there was a sharp increase in antibody titer both in serum and egg yolk. Three weeks after primary immunization, transference of antibodies specific to venom from serum to egg yolk was observed. At the $4^{\text {th }}$ week, the antibody response both in serum and yolk reached the highest level and maintained thereafter at least for 20 weeks (Fig. 1).

\section{Extraction, purification and biochemical identification of $\lg Y$}

The partially purified antibody preparation (crude extract) was obtained from the egg yolk by the watersoluble extraction method; then, it was fractioned by affinity chromatography into two peaks with strong IgY activity. They exhibited only one band (about $182 \mathrm{kDa}$ ) on SDS-PAGE under non-reducing conditions. However, under reducing conditions, they presented two bands, a heavy chain of IgY of about $66 \mathrm{kDa}$ and a light chain of IgY of about $25 \mathrm{kDa}$ (Fig. 2). Western blot showed that the purified sample could be recognized by HRP-rabbit anti-chicken IgY (Fig. 2). The average recovery of venom-specific IgY from 131 eggs was about $18.47 \%$ (Table 1). The venom-specific activities of IgY on different fractions including water-soluble fraction (WSF), salting-out fraction (SOF) and thiophilic-chromatography fraction (TCF) - were compared by ELISA. The results showed that the titer of TCF is twofold higher than that of SOF, and 16 times higher when compared with to

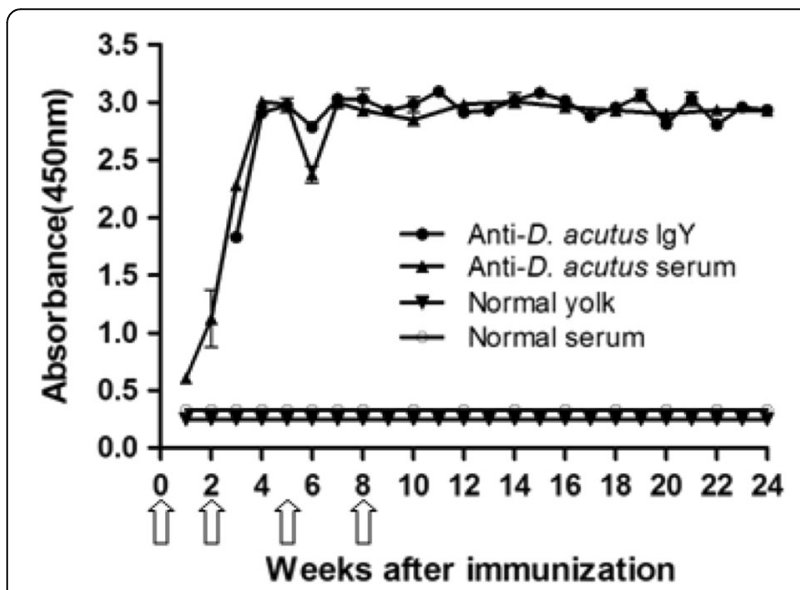

Fig. 1 Primary and secondary antibody response in serum and egg yolk of hens immunized with $D$. acutus venom. The activity against D. acutus venom of serum and WSF was assessed by ELISA. The white arrows indicate immunization

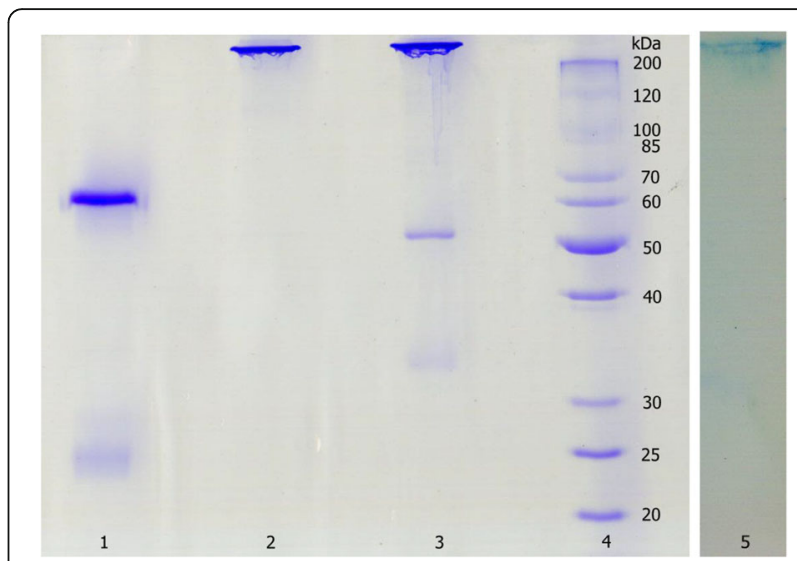

Fig 2 lgY samples from egg yolk analyzed by 12\% SDS-PAGE and identified by Western blot. Lane 1 and lane 2: $10 \mu \mathrm{g}$ of IgY after affinity chromatography (reducing and non-reducing conditions, respectively). Lane 3: $15 \mu \mathrm{g}$ of IgY's crude extract. Lane 4: molecular weight marker. Lane 5: identification of IgY with HRP-rabbit anti-chicken IgY by Western blot

WSF. Obviously, the three purification steps used resulted in the enrichment of venom-specific IgY.

\section{Immunological identification of IgY's crude extract}

Thirty micrograms of $D$. acutus venom was added to the central well, and the serial dilutions of the crude extract were added to the peripheral wells, respectively. The white precipitation lines occurred between the central well and each peripheral well indicated the immunological activities of IgY (Fig. 3). The titer of the crude extract by immunodiffusion was about $1 / 8$. About $1200 \mu \mathrm{g}$ of crude extract was added to the central well and the five different snake venoms (stored in our laboratory) were placed in the peripheral wells. The results indicated that the venoms of three species (T. albolabris, $D$. acutus and D. saxatilis in China) of Viperdae could react with the anti- $D$ acutus IgY, but the venoms of two species (B. multicinctus and N. atra in China) of Elapidae could not (Fig. 3).

\section{Evaluation of purified $\lg \mathrm{Y}$ titer}

According to the results of ELISA, the titer of specific anti-D. acutus venom IgY $(0.3 \mathrm{mg} / \mathrm{mL})$, which had been concentrated and desalted by ultrafiltration, was 1:40000 (Fig. 4).

\section{Antigen recognition repertoire of $\lg Y$}

Western blot analysis was carried out by using anti- $D$. acutus venom IgY as the first antibody and using HRPrabbit anti-chicken IgY as the second antibody. The results obtained demonstrated that not all protein components of $D$. acutus venom were recognized by IgY (Fig. 5). 
Table 1 Recovery ratio of proteins and titer of lgY fractions

\begin{tabular}{lccl}
\hline Fractions & $\begin{array}{c}\text { Titer of IgY by } \\
\text { ELISA }\left(\times 10^{4}\right)\end{array}$ & $\begin{array}{l}\text { Yolk proteins in } \\
131 \text { eggs }(\mathrm{g})\end{array}$ & $\begin{array}{l}\text { Recovery ratio } \\
\text { of proteins }(\%)\end{array}$ \\
\hline WSF & 3.3 & 31.83 & 100 \\
SOF & 25.7 & 12.59 & 39.56 \\
TCF & 51.3 & 5.88 & 18.47 \\
\hline
\end{tabular}

WSF Water-soluble fraction, SOF Salting-out fraction, TCF Thiophilic-chromatography fraction

\section{Neutralization studies of anti- $D$. acutus venom $\lg Y$}

Anti-D. acutus venom IgY that was in incubation with the venom prior to injection was capable of neutralizing the toxic components of venom. There was an increase in the survival rate of mice with increase in antivenom IgY. The proportion of $40 \mathrm{mg}$ of $\mathrm{IgY} / \mathrm{kg}$ of mouse body weight could produce $100 \%$ protection against a $3 \mathrm{LD}_{50}$ dose $(3 \times 2.93 \mathrm{mg} / \mathrm{kg})$ of venom and the value of $E D_{50}$ was $14.14 \mathrm{mg} I g Y / \mathrm{kg}$. There were no survivals in the control group.

Concerning hemorrhagic activity, about $10 \mu \mathrm{g}$ of $D$. acutus venom produced a hemorrhagic spot of $10 \mathrm{~mm}$ diameter (MHD). It was estimated that $350 \mu \mathrm{g}$ of $\operatorname{IgY}$ was able to completely neutralize the hemorrhage induced by the challenge doses of venom (3 MHD), whereas $150 \mu \mathrm{g}$ of IgY was able to neutralize about 50\% of the hemorrhagic effects. Control mice injected with physiological saline or IgY showed no hemorrhage, respectively (Fig. 6).

Regarding the edema-forming activity, mice immunized with $D$. acutus venom showed increase in footpad weight. About $1.3 \mu \mathrm{g}$ of $D$. acutus venom induced edema formation within $3 \mathrm{~h}$, which is considered as MED value. When anti-D. acutus venom IgY was incubated with the challenge doses of venom $(3 \times$ MED) for 30 min prior to injection, IgY antibodies were capable of inhibiting edema-forming activity induced by venom in a dose-

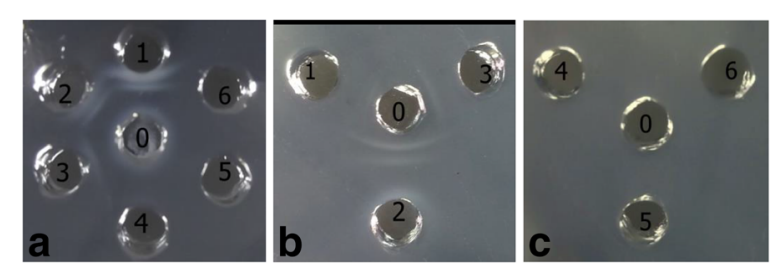

Fig 3 Immunological assessment of anti-D. acutus venom IgY against venom from five species of snakes found in China by immunodiffusion assay. a In the central well (0): D. acutus venom $(30 \mu \mathrm{g})$; in the peripheral wells: (1) anti-D. acutus IgY crude extract $(1200 \mu \mathrm{g}) ;(2-5)$ the serial dilutions $(1: 2,1: 4,1: 8$, and 1:16, respectively) of the crude extract; (6) physiological saline. $\mathbf{b}$ and $\mathbf{c}$ In the central well (0) anti-D. acutus IgY crude extract $(1200 \mu \mathrm{g})$ whereas the the peripheral wells contained $30 \mu \mathrm{g}$ of the following: (1) T. albolabris venom; (2) D. acutus venom; (3) D. saxatilis Emelianov venom; (4) B. multicinctus venom; (5) N. atra venom; and (6) physiological saline
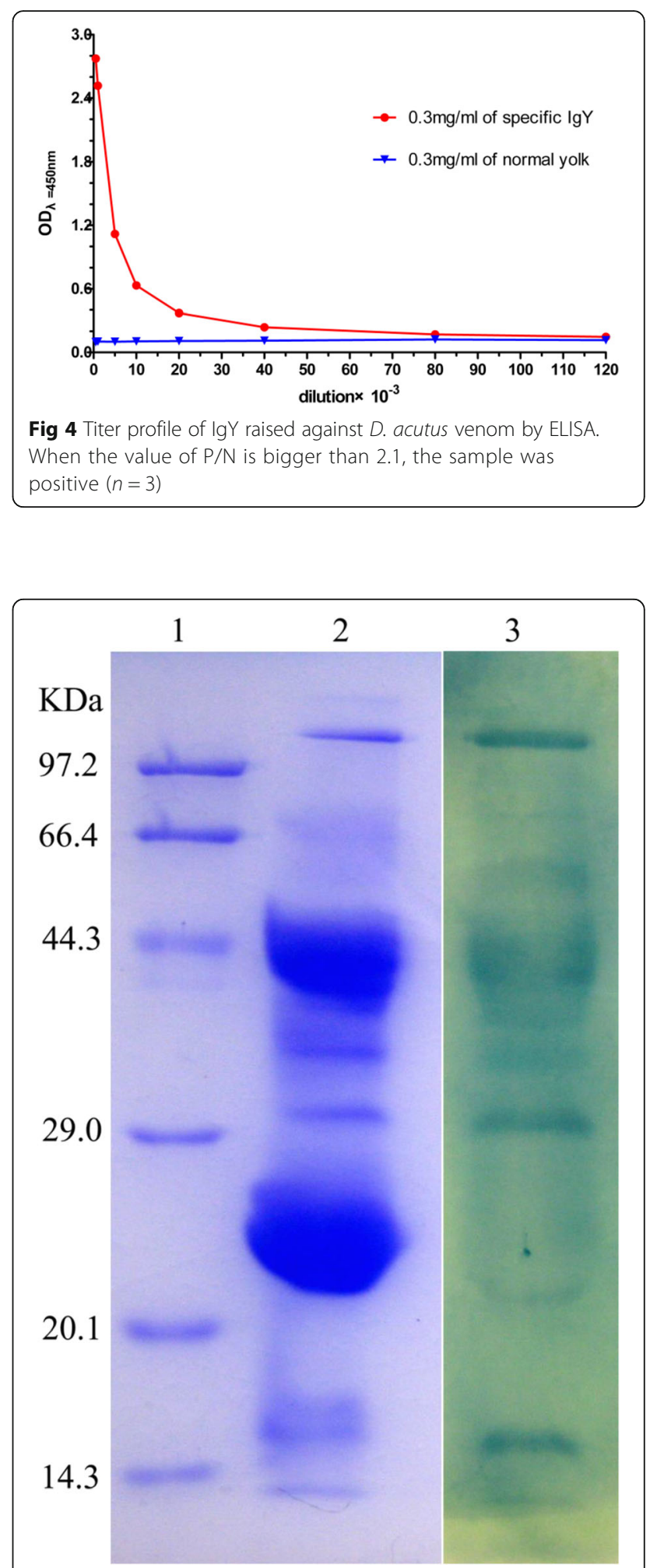

Fig 5 Antigen recognition repertoire of anti-D. acutus venom $\lg Y$ by Western blot. Lane 1: Molecular weight marker on SDS-PAGE. Lane 2: D. acutus venom $(50 \mu \mathrm{g})$ on SDS-PAGE. Lane 3: the protein components of $D$. acutus venom $(50 \mu \mathrm{g})$ on Western blot were recognized by IgY that was recognized by HRP-rabbit anti-chicken $\lg Y$ 


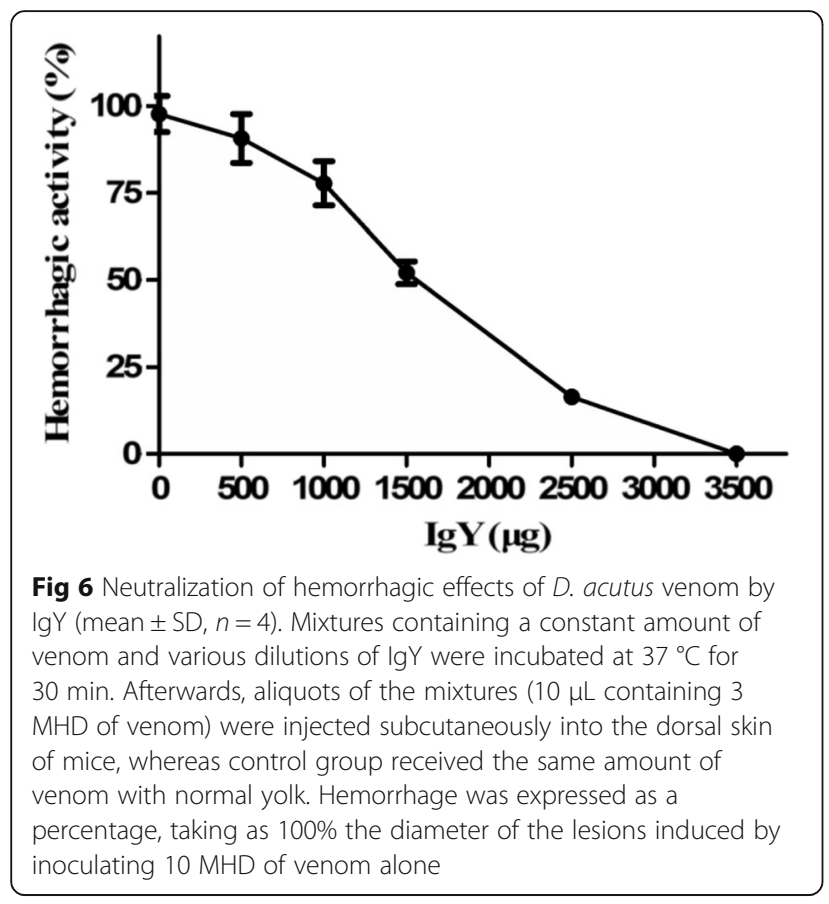

dependent manner (Fig. 7), and $\mathrm{ED}_{50}$ of $\mathrm{IgY}$ was about $124.68 \mu \mathrm{g}$.

In myotoxic activity, mice immunized with $D$. acutus venom showed increase in plasma CK activity. About $9.5 \mu \mathrm{g}$ of $D$. acutus venom induced myotoxic activity, which is considered a MMD value. When anti-D. acutus venom IgY was incubated with the challenge doses of venom $(3 \times \mathrm{MMD})$ for $30 \mathrm{~min}$ prior to injection, $\operatorname{IgY}$

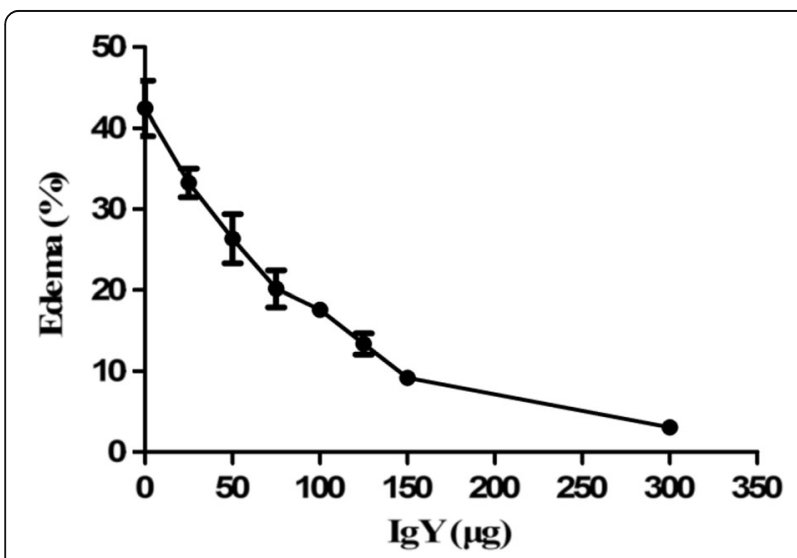

Fig 7 Neutralization of edema-forming activity of D. acutus venom by $\lg Y$ (mean $\pm S D, n=4$ ). Mixtures containing a constant amount of venom and various dilutions of $\lg Y$ were incubated at $37^{\circ} \mathrm{C}$ for $30 \mathrm{~min}$. Afterwards, aliquots of the mixtures ( $20 \mu \mathrm{L}$ containing three MED of venom) were injected into the right footpad of mice, whereas the left foot pad received $20 \mu \mathrm{L}$ of physiological saline. The weight of both feet was estimated $3 \mathrm{~h}$ after injection with an electronic scale and edema was expressed as the percentage increment in weight of the right footpad when compared to the left one antibodies were capable of inhibiting CK activity induced by venom in a dose-dependent manner (Fig. 8), and $\mathrm{ED}_{50}$ of IgY was about $766.43 \mu \mathrm{g}$.

\section{Discussion}

The venom of $D$. acutus, a snake endemic to China, possess proteins and peptides whose activity is mainly hemotoxic [28]. At the bite site, swelling, bruising, blistering and necrosis usually develop within a few minutes or hours and spread rapidly, sometimes the whole limb is affected [6]. The persistent bleeding from the fang marks and other previous partially healed wounds indicates coagulopathy, which is caused by the abundant metalloproteinases and serine proteases of $D$. acutus venom $[5,6]$. Its toxicity and pathophysiologic effects can be completely reversed by specific antivenom, which is conventionally produced from blood of large animals (horses or sheep) immunized with snake venoms $[8,10]$. As an alternative to the conventional antivenom with various side effects and the disadvantages of its preparation and production, antivenom IgY antibodies from egg yolk of chicken have considerable advantages $[8,16$, 29]. Previous studies have shown that chicken immunized with snake venom produces IgY that may neutralize the toxic and lethal effects of venom and may serve to treat domestic animals affected by snakebites $[16,21,30]$. The current study for the first time described the creation of anti-D. acutus venom IgY antibodies in chicken egg yolk and assessed their efficacy in neutralizing the lethal effect and other activities of $D$. acutus venom.

The antibody production started in serum eight days after the first injection of $D$. acutus venom and in egg

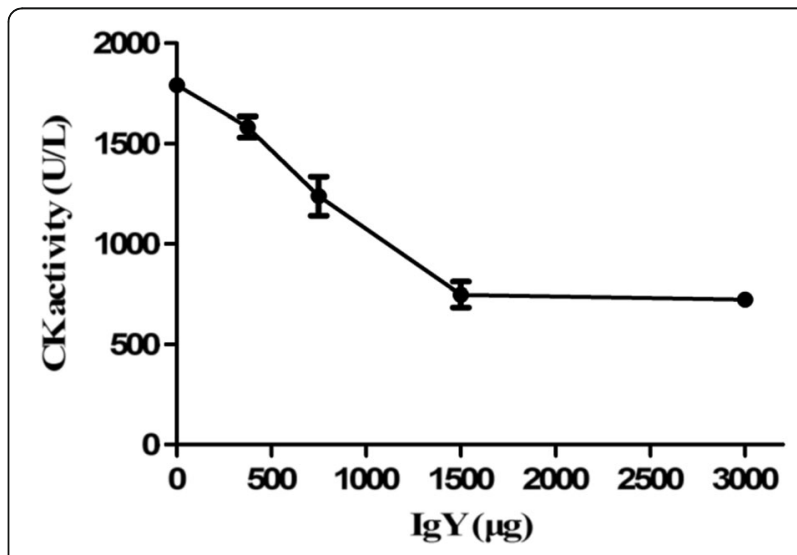

Fig 8 Neutralization of myotoxic activity of D. acutus venom by lgY (Mean $\pm \mathrm{SD}, n=4$ ). Mixtures containing a constant amount of venom and various dilutions of $\lg Y$ were incubated at $37^{\circ} \mathrm{C}$ for $30 \mathrm{~min}$. Then, aliquots of the mixtures $(50 \mu \mathrm{L}$ containing $3 \mathrm{MMD}$ of venom) were injected into the right gastrocnemius muscle of mice, whereas control group received $50 \mu \mathrm{L}$ of physiological saline. CK activity was expressed in U/L 
yolk at the $15^{\text {th }}$ day, increasing progressively along the immunization procedure, and attaining a plateau after the second booster, which was maintained thereafter (Fig. 1). This antibody response induced by $D$. acutus venom is for the first time obtained and is in good accordance with the antibody response of other snake venoms reported $[21,29,30]$.

As shown by Duan et al. [21], three steps were chosen to extract and purify the specific IgY antibodies from egg yolk. The average recovery of venom-specific IgY from 131 eggs was about $18.47 \%$ and $5.88 \mathrm{~g}$ of pure IgY was obtained (Table 1). The anti-D. acutus IgY antibodies generated were pure and specific to HRP-rabbit antichicken IgY, which was revealed by SDS-PAGE and Western blot analysis (Fig. 2). It was further confirmed by Western blot analysis that the anti- $D$. acutus IgY antibodies were able to recognize and bind to most protein components of D. acutus venom (Fig. 5). This suggests that the obtained IgY is a specific polyclonal antibody against $D$. acutus venom.

The immunodiffusion assay indicated the anti- $D$. acutus IgY not only reacted against $D$. acutus venom, but also against $T$. albolabris and $D$. saxatilis venoms. However, it did not recognize $B$. multicinctus or $N$. atra venoms (Fig. 4). The results indicated that venoms of $D$. acutus, T. albolabris and D. saxatilis of the same Viperidae family possibly share some common antigen epitopes. Conversely, they did not share any antigen epitopes with venoms of $B$. multicinctus or $N$. atra of the Elapidae family. These preclinical observations will provide some reference for clinicians to use antivenom or antibodies to treat bites caused by snakes from of the same family $[5,6]$.

According to the proteomic analysis, there were about 128 kinds of proteins and peptides identified in the venom of $D$. acutus [31]. The Western blot analysis showed that anti-D. acutus venom IgY antibodies mainly recognized a molecular weight range of the protein components in the venom (including $>97.2 \mathrm{kDa}$, 66.4$29 \mathrm{kDa}, 18-14.3 \mathrm{kDa}$ ), but did identify not other protein components (such as 20.1-29 kDa) (Fig. 6). Generally, protein or polypeptide components in such a mixture as crude venoms differ considerably in their abilities to elicit antibody response in immunized animals [16].

Our results indicated that protein or polypeptide components with molecular weight between 20.1 and $29 \mathrm{kDa}$ in $D$. acutus venom possibly lacked some immunogenicity for chickens. According to their biochemical characterization, the identified proteins in D. acutus venom were divided into three groups: serine proteases; P-I class snake venom metalloproteinases (SVMPs); and other proteins [32-34]. It was reported that the serine proteases and metalloproteinases in D. acutus venom, those whose molecular weight was distributed in the range of $>97.2 \mathrm{kDa}, 66.4-29 \mathrm{kDa}$ and $18-14.3 \mathrm{kDa}$, contributed to the major immunogenicity of $D$. acutus venom and underpinned the hemorrhagic, edema-forming and myotoxic acitivities [31]. Our observations confirmed that the polyvalent IgY antibodies raised against $D$. acutus venom are effective in the neutralization of the most important toxic effects including lethal, hemorrhagic, edema-forming and myotoxic acitivities of $D$. acutus venom (Fig. 6, 7 and 8). In addition, the neutralization showed a characteristic dose-dependent relationship.

\section{Conclusion}

In summary, IgY antibodies against $D$. acutus venom with high purity and titer were for the first time raised successfully in egg yolk by immunizing hens with snake venom. They were effective in neutralizing lethal, hemorrhagic, edema-forming and myotoxic acitivities of $D$. acutus venom. IgY could be an effective source to develop alternative treatment for snakebite victims in the future, either humans or other animals. However, further studies are required for testing the safety and efficacy of IgY.

\begin{abstract}
Abbreviations
CK: Creatine kinase; FCA: Freund's complete adjuvant; FIA: Freund's incomplete adjuvant; MED: Minimum edema-forming dose; MHD: Minimum hemorrhagic dose; MMD: Minimum myotoxic dose; OD: Optical density; PVDF: Polyvinylidene difluoride; SDS-PAGE: Sulfate-polyacrylamide gel electrophoresis; SOF: Salting-out fraction; SVMP: Snake venom metalloproteinase; TCF: Thiophilic-chromatography fraction; TMB: $3^{1}, 3^{1}, 5^{1}, 5^{1}$ tetramethylbenzidine; WSF: Water-soluble fraction.
\end{abstract}

\section{Acknowledgments}

The authors would like to thank the Natural Science Foundation of Chongqing (cstc2014yykfA0221, cstc2015shmszx 1225), Chongqing Forestry Department (Yulin keyan 2015-5) for supporting the present study.

\section{Funding}

This work was supported by Natural Science Foundation of Chongqing (cstc2014yykfA0221, cstc2015shmszx1225), Chongqing Forestry Department (Yulin keyan 2015-5).

\section{Authors' contributions}

J-HL, Q-YH and W-WW equally and mainly contributied to this study, X-DY provided the idea, gave supervision for experimental designs and finalized the manuscript, other authors helped in all the experiments during the study period. All authors read and approved the final manuscript.

\section{Competing interests}

The authors declare that they have no competing interests.

\section{Consent for publication \\ Not applicable.}

\section{Ethics approval and consent to participate}

All experimental procedures involving animals were carried out in accordance with the Chinese Animal Welfare Act. The present study was approved by Chongqing Municipal Public Health Bureau (protocol n. cstc2015).

\section{Publisher's Note}

Springer Nature remains neutral with regard to jurisdictional claims in published maps and institutional affiliations. 


\section{Author details}

Animal Toxin Group, Chongqing Key Laboratory of Animal Biology, Chongqing Engineering Research Center of Bioactive Substances, Engineering Research Center of Active Substances and Biotechnology, Ministry of Education, College of Life Science, Chongqing 401331, China. 2 Library, Chongqing Normal University, Chongqing 401331, China.

\section{Received: 7 November 2016 Accepted: 28 March 2017}

\section{Published online: 04 April 2017}

\section{References}

1. Kasturiratne A, Wickremasinghe AR, de Silva N, Gunawardena NK, Pathmeswaran A, Premaratna $\mathrm{R}$, et al. The global burden of snakebite: a literature analysis and modelling based on regional estimates of envenoming and deaths. PLoS Med. 2008;5(11):1591-604.

2. Chippaux JP. Snake-bites: appraisal of the global situation. Bull World Health Organ. 1998;76(5):515-24.

3. Habib AG. Public health aspects of snakebite care in West Africa: perspectives from Nigeria. J Venom Anim Toxins incl Trop Dis. 2013;19(1):27. doi:10.1186/1678-9199-19-27.

4. Theakston RD, Warrell DA, Griffiths E. Report of a WHO workshop on the standardization and control of antivenoms. Toxicon. 2003:41(5):541-57.

5. Zhao EM. Snakes of China. Hefei: Anhui Science and Technology Publishing House; 2006. p. 1-369.

6. Qin GP. China poisonous snake research. Nanning: Guangxi Science and Technology Press; 1998.

7. Bochner R. Paths to the discovery of antivenom serotherapy in France. J Venom Anim Toxins incl Trop Dis. 2016;22:20. doi:10.1186/s40409-016-0074-7.

8. Meenatchisundaram S, Parameswari G, Michael A, Ramalingam S. Studies on pharmacological effects of Russell's viper and Saw-scaled viper venom and its neutralization by chicken egg yolk antibodies. Int Immunopharmacol. 2008;8(8):1067-73.

9. Polson A, von Wechmar MB, Fazakerley G. Antibodies to proteins from yolk of immunized hens. Immunol Commun. 1980;9(5):495-514

10. Carroll SB, Thalley BS, Theakston RD, Laing G. Comparison of the purity and efficacy of affinity purified avian antivenoms with commercial equine crotalid antivenoms. Toxicon. 1992;30(9):1017-25.

11. Karlson-Stiber C, Persson H. Antivenom treatment in Vipera berus envenoming-report of 30 cases. J Intern Med. 1994;235(1):57-61.

12. Ferreira Júnior $A$, Santiago FM, Silva MV, Ferreira FB, Macêdo Júnior AG, Mota CM, et al. Production, Characterization and Applications for Toxoplasma gondii-Specific Polyclonal Chicken Egg Yolk Immunoglobulins. PLoS One. 2012;7(7):e40391. doi:10.1371/journal.pone.0040391.

13. Cova L. DNA-designed avian IgY antibodies: novel tools for research, diagnostics and therapy. J Clin Virol. 2005;34(Suppl):70-4.

14. Carlander D, Kollberg H, Wejåker PE, Larsson A. Peroral immunotheraphy with yolk antibodies for the prevention and treatment of enteric infections. Immunol Res. 2000;21(1):1-6.

15. Aguilar I, Sanchez EE, Giron ME, Estrella A, Guerrero B, Rodriguez-Acosta FA. Coral snake antivenom produced in chickens (Gallus domesticus). Rev Inst Med Trop Sao Paulo. 2014;56(1):61-6.

16. Almeida CM, Kanashiro MM, Rangel Filho FB, Mata MF, Kipnis TL, da Silva WD. Development of snake antivenom antibodies in chickens and their purification from yolk. Vet Rec. 1998;143(21):579-84.

17. Schade R, Calzado EG, Sarmiento R, Chacana PA, Porankiewicz-Asplund J, Terzolo HR. Chicken egg yolk antibodies (IgY-technology): a review of progress in production and use in research and human and veterinary medicine. Altern Lab Anim. 2005;33(2):129-54.

18. Karlsson M, Kollberg H, Larsson A. Chicken IgY: utilizing the evolutionary advantage. Worlds Poult Sci J. 2004;60(3):341-8.

19. Dias da Silva W, Tambourgi DV. IgY: a promising antibody for use in immunodiagnostic and in immunotherapy. Vet Immunol Immunopathol. 2010;135(3-4):173-80.

20. Zhang WW. The use of gene-specific lgY antibodies for drug target discovery. Drug Discov Today. 2003;8(8):364-71.

21. Duan HL, He QY, Zhou B, Wang WW, Li B, Zhang YZ, et al. Anti-Trimeresurus albolabris venom IgY antibodies: preparation, purification and neutralization efficacy. J Venom Anim Toxins incl Trop Dis. 2016;22(1):23. doi:10.1186/ s40409-016-0078-3.

22. Lowry OH, Rosebrough NJ, Farr AL, Randall RJ. Protein measurement with the Folin phenol reagent. J Biol Chem. 1951;193(1):265-75.
23. Laemmli UK. Cleavage of structural proteins during the assembly of the head of bacteriophage T4. Nature. 1970;227(5259):680-5.

24. Towbin H, Staehelin T, Gordon J. Electrophoretic transfer of proteins from polyacrylamide gels to nitrocellulose sheets: procedure and some applications. Proc Natl Acad Sci U S A. 1979;76(9):4350-4.

25. Ouchterlony O. Antigen-antibody reactions in gels. Acta Pathol Microbiol Scand. 1949:26(4):507-15.

26. W.H.O. Progress in the Characterization of Venoms and Standardization of Antivenoms; Offset Publication, Ed. Geneva: World Health Organization; 1981;58:1-44.

27. Gutiérrez JM, Gené JA, Rojas G, Cerdas L. Neutralization of proteolytic and hemorrhagic activities of Costa Rican snake venoms by a polyvalent antivenom. Toxicon. 1985:23(6):887-93.

28. Van Dong L, le Quyen K, Eng KH, Gopalakrishnakone P. Immunogenicity of venoms from four common snakes in the South of Vietnam and development of ELISA kit for venom detection. J Immunol Methods. 2003;282(1-2):13-31.

29. Rojas E, Quesada L, Arce V, Lomonte B, Rojas G, Gutiérrez JM. Neutralization of four Peruvian Bothrops sp. snake venoms by polyvalent antivenoms produced in Perú and Costa Rica: preclinical assessment. Acta Trop. 2005; 93(1):85-95.

30. Paul K, Manjula J, Deepa EP, Selvanayagam ZE, Ganesh KA, Subba Rao PV. Anti-Echis carinatus venom antibodies from chicken egg yolk: isolation, purification and neutralization efficacy. Toxicon. 2007;50(7):893-900.

31. Chunhong $\mathrm{H}$, Xiaodong H, Yi K, Wutong W. Coupled chromatography for assay of the venom proteome of the snake Agkistrodon acutus: an effective strategy for discovery of active components. Chromatographia. 2009;69(9-10): 879-86

32. Zhu Z, Gong P, Teng M, Niu L. Purification, N-terminal sequencing, partial characterization, crystallization and preliminary crystallographic analysis of two glycosylated serine proteinases from Agkistrodon acutus venom. Acta Crystallogr D Biol. 2003;59(Pt 3):547-50

33. Wang YM, Wang SR, Tsai $H_{H}$. Serine protease isoforms of Deinagkistrodon acutus venom: cloning, sequencing and phylogenetic analysis. Biochem J. 2001;354(Pt 1):161-8.

34. Lou Z, Hou J, Liang X, Chen J, Qiu P, Liu Y, et al. Crystal structure of a nonhemorrhagic fibrin (ogen) olytic metalloproteinase complexed with a novel natural tri-peptide inhibitor from venom of Agkistrodon acutus. J Struct Biol. 2005;152(3):195-203

\section{Submit your next manuscript to BioMed Central and we will help you at every step:}

- We accept pre-submission inquiries

- Our selector tool helps you to find the most relevant journal

- We provide round the clock customer support

- Convenient online submission

- Thorough peer review

- Inclusion in PubMed and all major indexing services

- Maximum visibility for your research

Submit your manuscript at www.biomedcentral.com/submit
) Biomed Central 